\title{
Measurement of exhaust gas emissions from miniature turbojet engine
}

\begin{abstract}
This paper presents a methodology developed to measure exhaust gas emissions during operation of a miniature turbojet engine, using a laboratory test rig. The rig has been built for research and development works aimed at modelling and investigating processes and phenomena occurring in jet engines. The miniature jet engines, similarly to full-scale ones used commonly in air transport, are characterized by variable exhaust gas emissions, depending on engine operating parameters. For this reason, an attempt has been made to determine the characteristic features of miniature engine operation modes and to define the variability of operation parameters and exhaust gas emissions as a function of time. According to the authors, the preliminary tests allowed for defining specific profile of engine test, which enables proper measurement regarding exhaust gas emissions using the miniature jet engine. The paper also presents test results for Jet A-1 fuel, according to the used methodology.
\end{abstract}

Key words: combustion process, effect on environment, exhaust gas emission, miniature turbojet engine

\section{Introduction}

Aviation is one of the fastest growing modes of transport. During recent years, the increasing number of aircrafts has been associated with higher intensity of carried out aviation operations. This causes an increasing demand for fuel, which is the power supply for jet engines that leads to an increase of harmful exhaust emissions. Aviation is currently the fastest growing source of $\mathrm{CO}_{2}$ emissions [1]. Generated pollutants negatively affect the quality of the air that surrounds us and conduce to greenhouse effect intensification.

For this reason, in 2012, the EU emissions trading system (EU ETS) was introduced into aviation sector. The system will include the exhaust emissions generated by civil aviation. Airlines carrying out flights all over Europe, and to and from Europe, are obliged to obtain entitlement to emissions generated during such flights. Such deliberations justify the advisability of taking various research and development works regarding the effect of aviation on environment $[2,3]$.

Turbine engines as the propulsion of modern aircrafts, depending on engine operating parameters, are characterized by variable emissions of harmful exhaust gases. The aviation engines whose rated thrust is greater than $26.7 \mathrm{kN}$ are subject to emission certifications. The measurement procedure and assessment of harmful exhaust emissions are included in Annex 16 to the Convention on International Civil Aviation - Environmental protection (Volume II - Aircraft Engine Emissions). Landing and Take Off cycle consisting of ground-based tests. The separate test steps correspond to the following operating modes: take off, climb, approach and taxi/ground idle (Fig. 1).

The engine is tested at specified thrust settings [5]. The reference emissions of LTO cycle for the calculation and reporting of gaseous emissions are represented by the following time in each operating mode (Tab. 1).

Due to high costs of tests using the test rig with full scale jet engine, more and more tests are conducted using miniature jet engines $[6,7]$. Such engines are used not only in scientific and research work, but are also used as a propulsion for aerial targets.

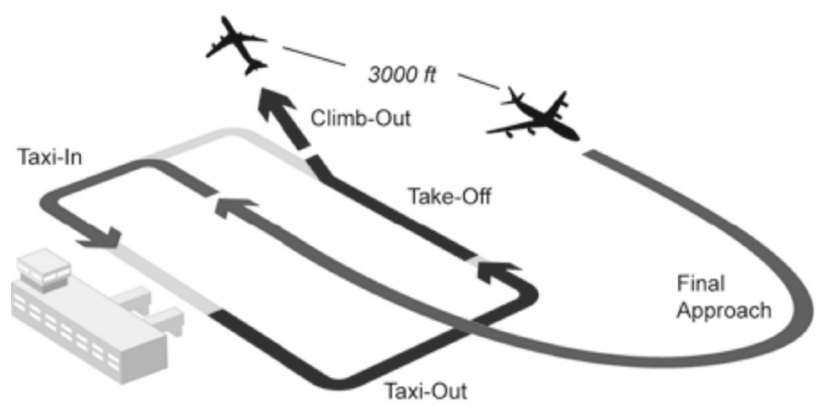

Fig. 1. ICAO reference LTO cycle [4]

Table 1. LTO operating mode

\begin{tabular}{|l|c|c|}
\hline Operating mode & Thrust setting & $\begin{array}{c}\text { Time in operating } \\
\text { mode [min] }\end{array}$ \\
\hline Take-off & $100 \%$ rated thrust & 0.7 \\
\hline Climb & $85 \%$ rated thrust & 2.2 \\
\hline Approach & $30 \%$ rated thrust & 4.0 \\
\hline Taxi/ground idle & $7 \%$ rated thrust & 26.0 \\
\hline
\end{tabular}

The main advantage of the miniature turbojet engine application is a small amount of fuel necessary for tests. This is especially important in case of research work regarding alternative jet fuels. Nowadays availability of new, experimental fuels or components is the major restriction for large-scale tests on real jet engines. The reason for that situation is that most of innovative technologies for aviation biofuels are in an experimental stage, and only small volumes of such products are available.

The use of alternative fuels for aviation is currently very important regarding ecology. One of the main methods to restrict the harmful exhaust emission is to introduce various components into aviation fuel, including biocomponents and biofuels. The subject literature includes many publications related to alternative fuel testing using a small scale turbine engine [8-11].

In case of full-scale turbine engines there is a test procedure regarding harmful exhaust gas emissions (LTO cycle). There are no standards concerning miniature engines of considerably lower thrust. It seems that a proper selection of 
test engine profile is very important for correct accomplishment of research goals, especially regarding the exhaust gas emission. The literature shows that many publications include test results without defined profile of engine test, especially without the time of engine operation at given range [9-11]. The paper [12] shows a profile of an engine test, where operation time at specific rotational speed was $15 \mathrm{~s}$. Such time is surely enough to obtain the stability of operation parameters of a miniature engine, but the stability of exhaust gas emissions and measurement of their actual values for this time are questionable.

This paper presents the profile of an engine test regarding the measurement of harmful exhaust emission during operation of a miniature jet engine, using the laboratory test rig. The paper also presents test results obtained according to assumptions made.

\section{Experimental details and results}

\subsection{Test rig description}

The research work described in this paper was conducted using laboratory test rig (Miniature Jet Engine Test Rig -MiniJETRig). Construction of the test rig and research potential were presented in the paper [13].

The miniature turbojet engine is manufactured by polish company - JETPOL [14]. It has a single - stage radial compressor driven by a single - stage axial turbine and an annular combustion chamber with a set of vaporizer tubes. A miniature jet engine has been prepared in two versions: metal and glass housings. Furthermore two exhaust systems: with straight duct and convergent nozzle are available. The miniature turbojet engine is protected by an Electronic Control Unit (ECU). ECU controls: maximum and minimum value of exhaust gas temperature and revolutions per minute, pump control voltage as a function of rpm. The basic of miniature turbojet engine specifications are shown in Table 2.

Table 2. Turbine engine specifications

\begin{tabular}{|l|c|}
\hline Engine type & Turbojet - single spool \\
\hline Series engine & GTM 140 \\
\hline Compressor & Single stage radial compressor \\
\hline Combustion chamber & Annular combustion chamber \\
\hline Turbine & Single stage axial flow turbine \\
\hline Pressure ratio & $2.8: 1$ \\
\hline Minimum RPM & 33000 \\
\hline Maximum RPM & 120000 \\
\hline Thrust at max. RPM & $140 \mathrm{~N}$ \\
\hline Fuel consumption at max. RPM & $500 \mathrm{ml} / \mathrm{min}$ \\
\hline Mass flow at max. RPM & $0.35 \mathrm{~kg} / \mathrm{s}$ \\
\hline Max. exhaust gas temperature & $1023 \mathrm{~K}$ \\
\hline
\end{tabular}

The above-mentioned data describe the engine with automatic start using an electrical starter and exhaust system with a convergent nozzle. For the purpose of this paper, the exhaust system with straight duct was used and the engine was started up with compressed air. Such modification allows to measure the intake air flow rate and obtain maximum thrust of $70 \mathrm{~N}$.
During the tests, the engine operating parameters were recorded: thrust, rotational speed, exhaust gas temperature (T) and fuel consumption. The following sensors are installed on the MiniJETRig:

a) the engine thrust is measured by a load cell series KM302 (Megatron) with an indicator MD150T. Measurement range is $0-300$ Newton. Sensitivity of used sensor is 1.93 $\mathrm{mV} / \mathrm{V}$;

b)rotational speed sensor (Photodiode type SFH 203 FA) with a $0-120000 \mathrm{rpm}$ range;

c)thermocouples type K (TP-42-WTTKbm-1xK) with measuring range of 233-1273 K. Maximum permissible error is $\pm 0.4 \%$ measured temperature;

d)turbine flow meter (Digmesa Flowmeter FHKSC) with measuring range of $0.033-21 / \mathrm{min}$ and an accuracy $\pm 2 \%$.

The harmful components of exhaust gas were measured using a portable exhaust analyser. A probe of this analyser was used to sample the exhaust gas at the end of the exhaust system, to determine the concentration of $\mathrm{CO}, \mathrm{CO}_{2}$ and $\mathrm{NO}_{\mathrm{x}}$ (Table 3).

Table 3. Details of measurement equipment for gas emissions

\begin{tabular}{|l|c|c|c|}
\hline Parameter & Sensor type & Range & Unit \\
\hline $\mathrm{CO}$ & electrochemical & $0-2000$ & $\mathrm{ppm}$ \\
\hline $\mathrm{CO}_{2}$ & infrared & $0-25$ & $\%$ \\
\hline $\mathrm{NO}$ & electrochemical & $0-500$ & $\mathrm{ppm}$ \\
\hline $\mathrm{NO}_{2}$ & electrochemical & $0-100$ & $\mathrm{ppm}$ \\
\hline
\end{tabular}

The miniature GTM-140 series jet engine runs on conventional fuel used in the aviation industry, Jet A-1 with 3-5\% AeroShell Turbine Oil 560. This volume of oil is recommended by the engine manufacturer for bearing lubrication.

However, oil added to the fuel adversely effects on assessment of the combustion process through contamination of the results due to the presence of oil. The test rig was modified by the separation of the fuel supply system on two different systems: primary to supply fuel to the combustion chamber, and secondary to supply fuel pre-mixed with oil to bearings. This solution allows for supply clean jet fuel to the combustion chamber.

\subsection{Development of methodology and discussion}

The preliminary tests took place according to the following engine test procedure. Upon ignition, the engine was given maximum of 60 seconds to reach a steady state, whereby the engine speed remained constant at approximately $33000 \mathrm{rpm}$ (idle speed). Rotational speed was raised from 40000 to $110000 \mathrm{rpm}$ with the interval at $10000 \mathrm{rpm}$. The steady state (in the range $\pm 2000 \mathrm{rpm}$ ) at each interval lasted 30 seconds. At the end of a profile of the test run, rotational speed was decreased to $70000 \mathrm{rpm}$ and the engine was shut down. The sampling rate was five times per second for all measurement parameters. The results of engine operation parameters profile and emissions for individual exhaust gas components at two selected rotational speeds are illustrated in Fig. 2-8. 


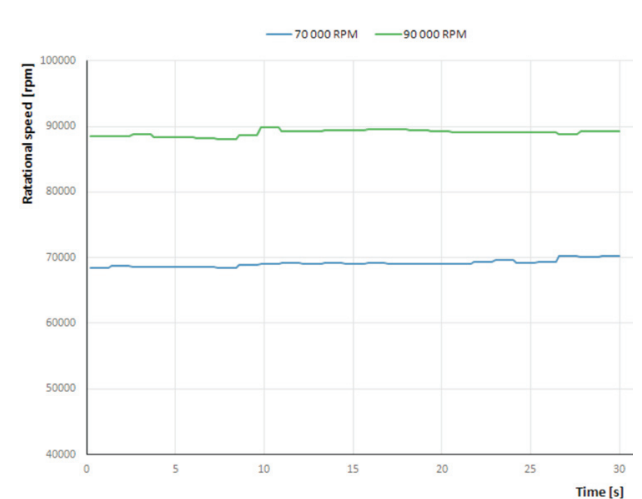

Fig. 2. Rotational speed as a function of time

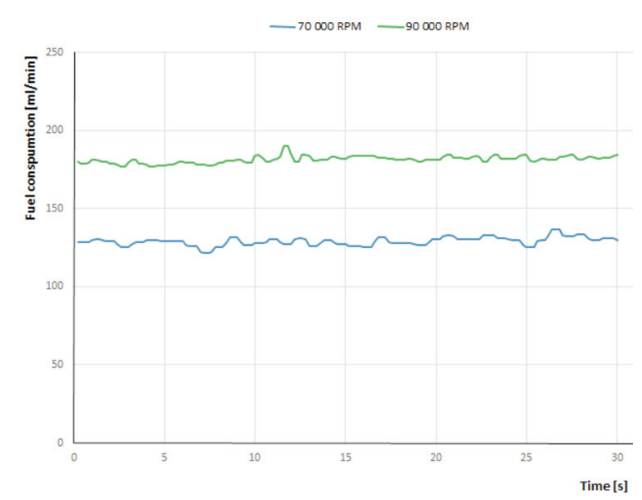

Fig. 4. Fuel consumption as a function of time

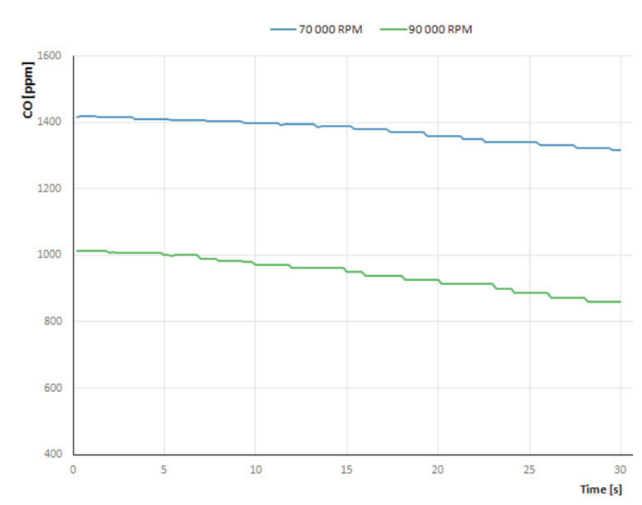

Fig. 6. $\mathrm{CO}$ emission as a function of time

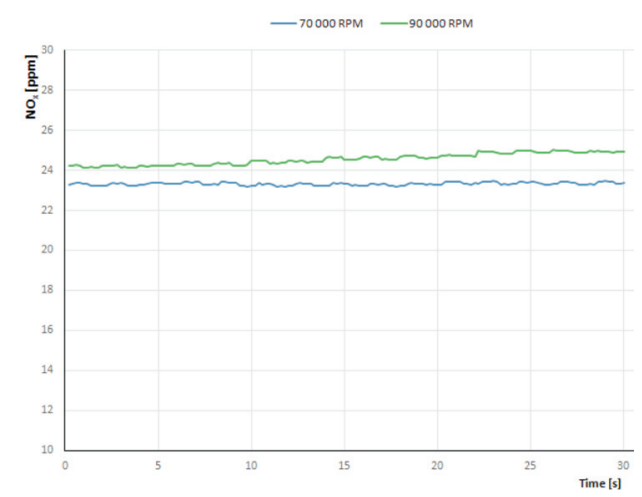

Fig. 8. $\mathrm{NO}_{\mathrm{x}}$ emission as a function of time

According to the above results, it can be observed that after reaching given rotational speed, the measured operating engine parameters quickly achieved stabilization which is

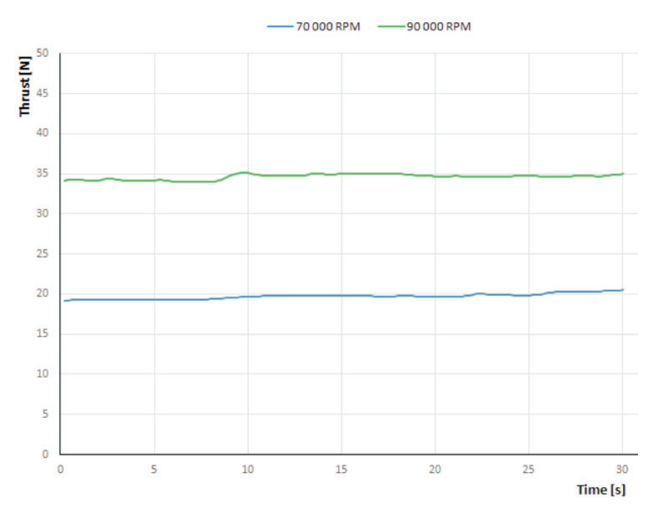

Fig. 3. Thrust as a function of time

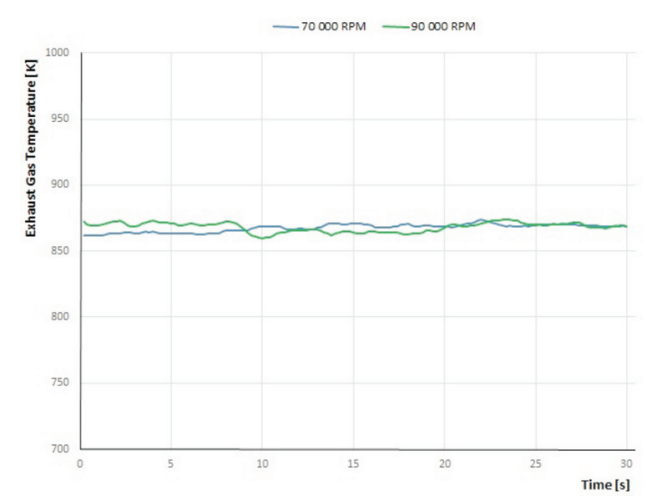

Fig. 5. Exhaust gas temperature as a function of time

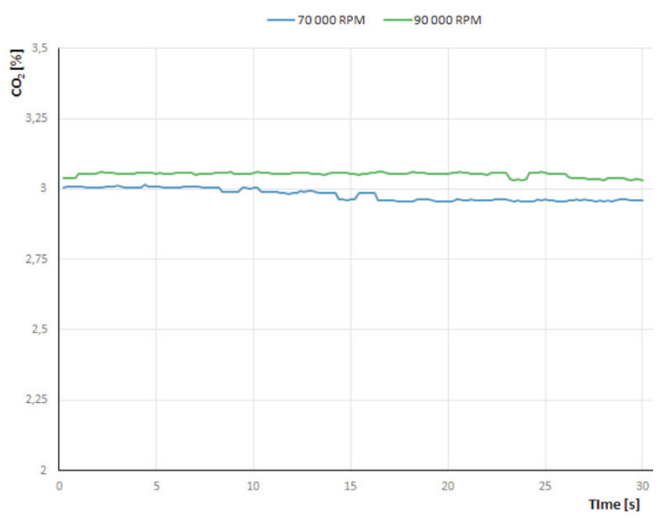

Fig. 7. $\mathrm{CO}_{2}$ emission as a function of time

maintained during all the accepted time of operation at a given speed. The changes in emissions of $\mathrm{CO}_{2}$ and $\mathrm{NO}_{x}$ are small at the assumed time. However, in the case of $\mathrm{CO}$, it can be seen distinctly that the time of $30 \mathrm{~s}$ at two taken speed ranges was not sufficient to stabilize the emission. Accordingly, it was necessary to modify the accepted profile of the engine test regarding the range of harmful exhaust emissions.

Subsequent engine test procedure was developed based on LTO cycle that was introduced in order to certify fullscale turbine engines. The rotational speeds for miniature engine, corresponding to relative values of the obtained thrust was determined (Tabl. 4). Since the engine manufacturer recommends only very short operation times at speed corresponding to maximum thrust (the engine is under the high- 
est load then), tests at such rotational speed were excluded. Additionally, a new speed of $88000 \mathrm{rpm}$ corresponding to $50 \%$ of maximum thrust was added.

Table 4. Comparison LTO cycle with profile of engine test

\begin{tabular}{|l|c|c|c|}
\hline LTO operational mode & \multicolumn{2}{|c|}{ MiniJETRig } \\
\hline Operating phase & Thrust setting & Thrust & Rotational speed \\
\hline Take-off & $100 \%$ rated thrust & - & - \\
\hline Climb & $85 \%$ rated thrust & $85 \%$ & 112000 \\
\hline- & - & $50 \%$ & 88000 \\
\hline Approach & $30 \%$ rated thrust & $30 \%$ & 70000 \\
\hline Taxi ground idle & $7 \%$ rated thrust & $7 \%$ & 39000 \\
\hline
\end{tabular}

Further bench tests were carried out at four specific rotational speeds (based on Table 4) for different times of operation. The results have been shown in Fig. 9-12. They show $\mathrm{CO}$ emission change course, which was unstable during initial phase of tests.

At rotational speed of $112000 \mathrm{rpm}$, testing was carried out only for $60 \mathrm{~s}$. Such a time value was accepted because according to the engine manufacturer recommendations the engine should not be operated at a speed higher than $100000 \mathrm{rpm}$ over the longer periods of time. The CO emission stability at engine tests was accomplished for a speed of $39000 \mathrm{rpm}$ and $70000 \mathrm{rpm}$ in $90 \mathrm{~s}$. In case of rotational speed of $88000 \mathrm{rpm}$, stability was accomplished after $150 \mathrm{~s}$.

Different trends, and thus different values for $\mathrm{CO}$ emission at a given speed are caused by different ambient conditions during testing.

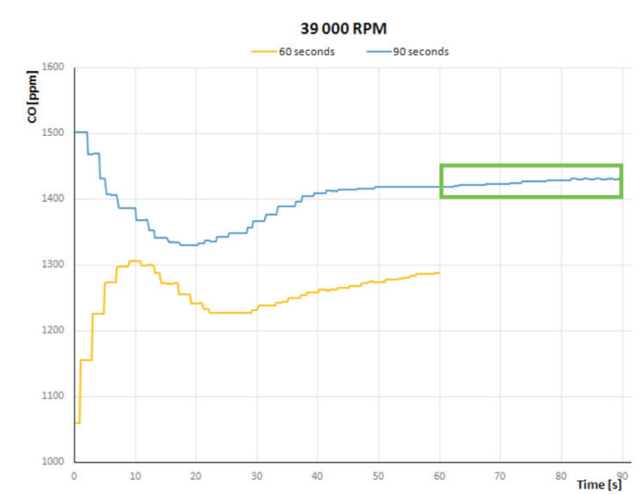

Fig. 9. CO emission as a function of time for $39000 \mathrm{rpm}$

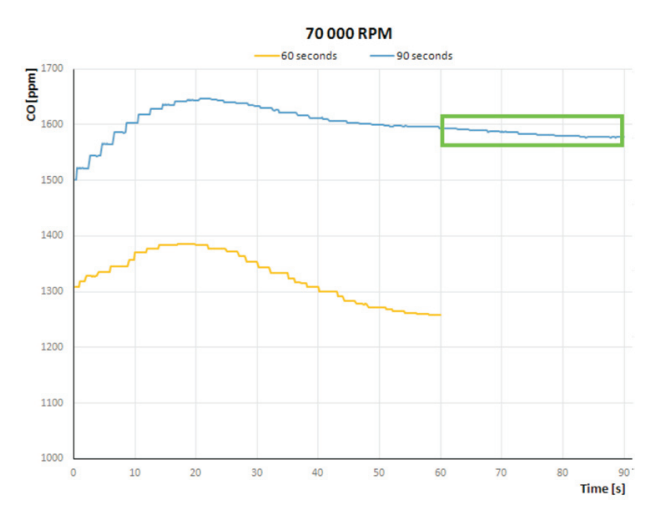

Fig. 10. CO emission as a function of time for $70000 \mathrm{rpm}$
The calculations regarding a mean value and standard deviation for $\mathrm{CO}$ emission as a function of time are included in Table 5.

Table 5. CO emission calculations

\begin{tabular}{|l|c|c|}
\hline Parameter & \multicolumn{2}{|c|}{$\mathrm{CO} \pm \mathrm{s}[\mathrm{ppm}]$} \\
\hline Period & $\begin{array}{c}\text { Entire test } \\
\text { (at given speed) }\end{array}$ & $\begin{array}{c}\text { Last } 30 \mathrm{~s} \text { of test } \\
\text { (at given speed) }\end{array}$ \\
\hline $39000 \mathrm{rpm}$ & $1402 \pm 37(90 \mathrm{~s})$ & $1425 \pm 4$ \\
\hline $70000 \mathrm{rpm}$ & $1600 \pm 27(90 \mathrm{~s})$ & $1583 \pm 5$ \\
\hline $88000 \mathrm{rpm}$ & $1132 \pm 112(150 \mathrm{~s})$ & $1044 \pm 2$ \\
\hline $112000 \mathrm{rpm}$ & $632 \pm 33(60 \mathrm{~s})$ & $608 \pm 5$ \\
\hline
\end{tabular}

The obtained results allow to adopt a constant rule for data analysis regarding components of exhaust gas and engine operation parameters. The engine test results, at a given rotational speed, covering only the last $30 \mathrm{~s}$ of engine operation (green frame in Fig. 9-12) are analysed. According to the authors of the paper, such methodology allows to obtain reliable value of specific component emission corresponding to defined conditions of miniature jet engine operation.

Based on the test results, the final profile of the engine test was determined (Fig. 13). According to this profile, the fundamental testing was carried out and the results were presented in Chapter 4 of this paper. Acceptable range of rotational speed variation at selected operation mode is $\pm 2000 \mathrm{rpm}$.

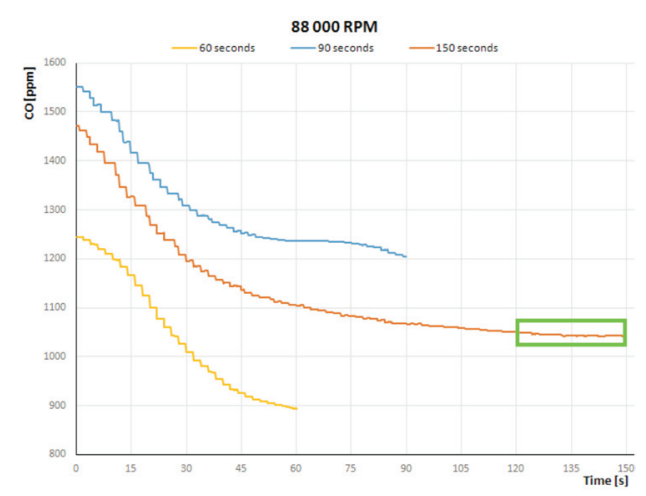

Fig. 11. CO emission as a function of time for $88000 \mathrm{rpm}$

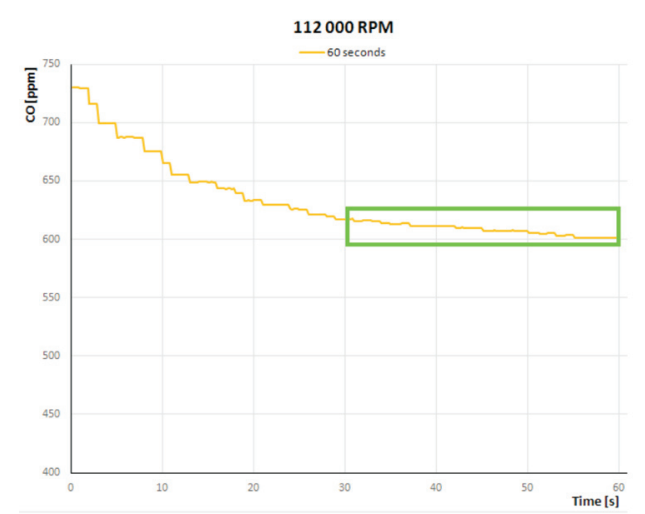

Fig. 12. CO emission as a function of time for $112000 \mathrm{rpm}$ 


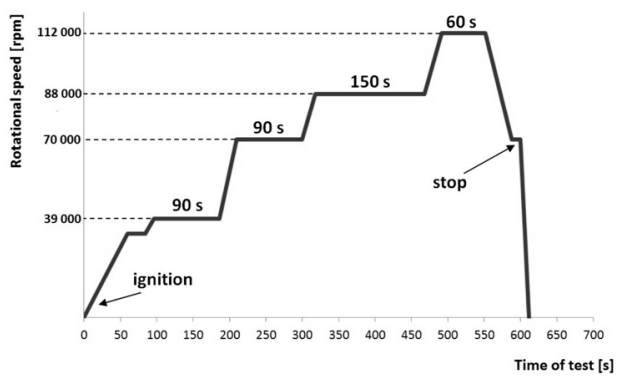

Fig. 13. Profile of engine test

\subsection{Verification of methodology}

The research was carried out using the test rig fuelled with jet fuel Jet A-1 from the same production batch (Merox process). The tests were repeated four times during one day with the ambient conditions shown in Table 6. The average value of the parameters was then calculated for each rotational speed.

Table 6. Ambient test conditions

\begin{tabular}{|l|c|c|}
\hline Test number & $\mathrm{P}_{\mathrm{o}}(\mathrm{bar})$ & $\mathrm{T}_{\mathrm{o}}(\mathrm{K})$ \\
\hline Test 1 & 1.010 & 288.8 \\
\hline Test 2 & 1.010 & 288.8 \\
\hline Test 3 & 1.011 & 287.9 \\
\hline Test 4 & 1.012 & 286.9 \\
\hline
\end{tabular}

Fig. 14-16 present engine parameters at the selected rotational speeds. The results are similar to the characteristics obtained on a full-scale jet engines [15]. Thrust produced from the engine is proportional to the amount of fuel consumed.

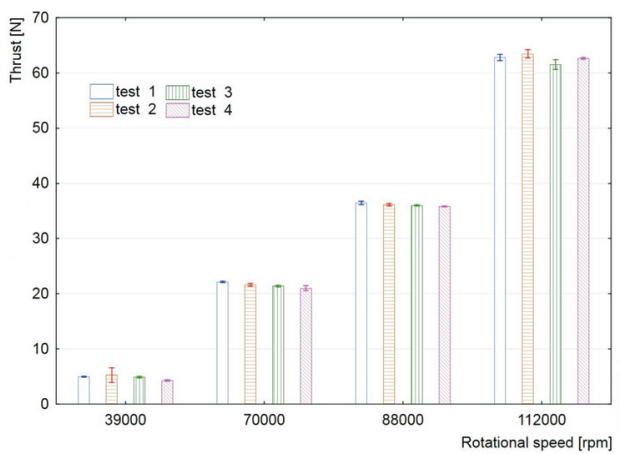

Fig. 14. Thrust at the selected rotational speeds

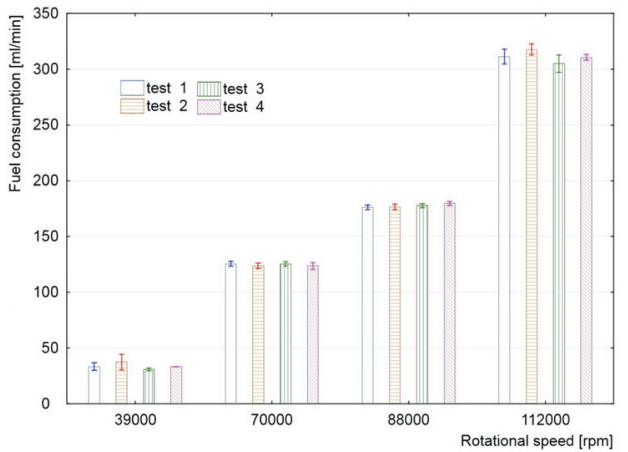

Fig. 15. Fuel consumption at the selected rotational speeds

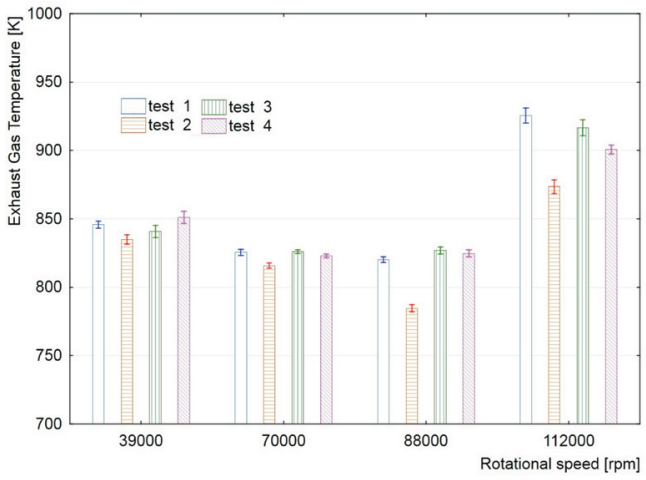

Fig. 16. $\mathrm{T}$ at the selected rotational speeds

A general trend for $\mathrm{CO}$ emissions for jet engines is that they are highest at low power conditions, and decrease with increasing power output. CO data (Fig. 17) follow this trend in the range of rotational speed above $70000 \mathrm{rpm}$. A general trend for $\mathrm{NO}_{\mathrm{x}}$ emissions [16] is that they increased as engine speed increased.

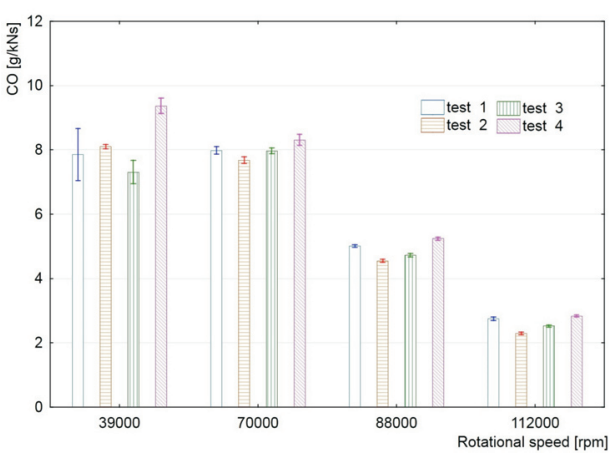

Fig. 17. CO emission at the selected rotational speeds

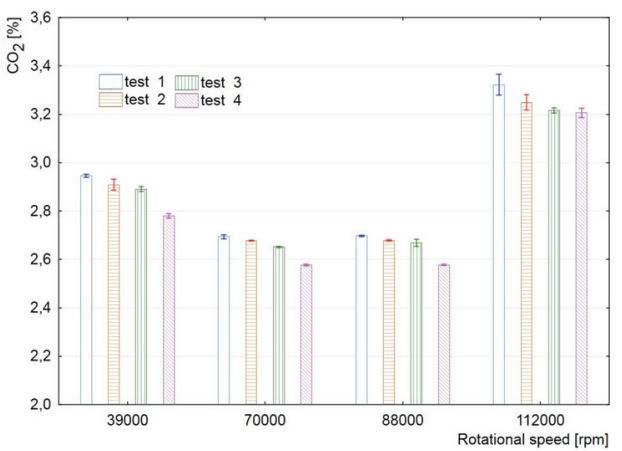

Fig. 18. $\mathrm{CO}_{2}$ emission at the selected rotational speeds

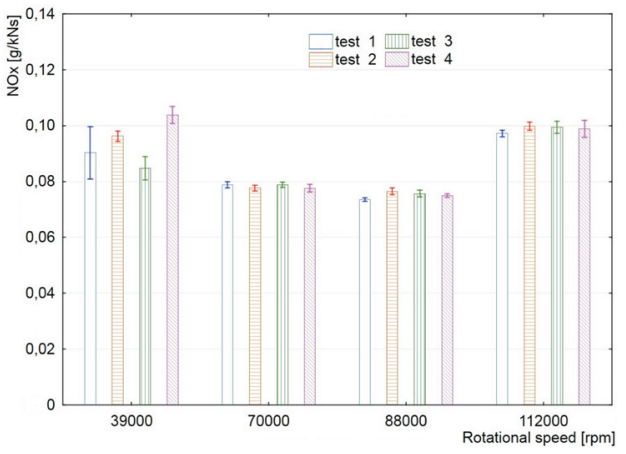

Fig. 19. $\mathrm{NO}_{\mathrm{x}}$ emission at the selected rotational speeds 
The test results presented in Fig. 14-19 regarding both engine operating parameters and exhaust gas emissions, show that results of four independent engine tests carried out on the same day and at ambient conditions have the same trends. For engine operating parameters, the obtained results have similar values.

The measurement data analysis for selected test regarding one selected rotational speed are included in Table 7.

Table 7. The analysis of selected measurement data

\begin{tabular}{|l|c|c|c|c|c|c|}
\hline \multicolumn{7}{|c|}{ Test 3 for $88000 \mathrm{rpm}$} \\
\hline $\begin{array}{l}\text { Parame- } \\
\text { ter }\end{array}$ & $\begin{array}{c}\text { Thrust } \\
{[\mathrm{N}]}\end{array}$ & $\begin{array}{c}\text { Fuel con- } \\
\text { sumption } \\
{[\mathrm{ml} / \mathrm{min}]}\end{array}$ & $\begin{array}{c}\mathrm{T}_{\mathrm{EG}} \\
{[\mathrm{K}]}\end{array}$ & $\begin{array}{c}\mathrm{CO} \\
{[\mathrm{g} / \mathrm{kNs}]}\end{array}$ & $\begin{array}{c}\mathrm{CO}_{2} \\
{[\%]}\end{array}$ & $\begin{array}{c}\mathrm{NO}_{\mathrm{x}} \\
{[\mathrm{g} / \mathrm{kNs}]}\end{array}$ \\
\hline $\begin{array}{l}\text { Mean } \\
\text { value }\end{array}$ & 36.0 & 177.8 & 827 & 4.73 & 2.67 & 0.076 \\
\hline $\begin{array}{l}\text { Standard } \\
\text { deviation }\end{array}$ & \pm 0.1 & \pm 1.8 & \pm 3 & \pm 0.06 & \pm 0.01 & \pm 0.001 \\
\hline
\end{tabular}

\section{Bibliography}

[1] Gawron, B., Kaźmierczak, U. Hydrocarbon biocomponents use in aviation fuels - preliminary analysis of issues, Journal of KONBIN. 2013, 27/28, 63-72.

[2] Kinsey, S.J. et al. Characterization of Emissions from Commercial Aircraft Engines during the Aircraft Particle Emissions eXperiment (APEX) 1 to 3, 2009.

[3] Lobo, P., Whitefield, P.D., Hagen, D.E. et al. The development of exhaust speciation profiles for commercial jet engines, 2007.

[4] Fleuti, E., Maraini, S. Air Quality Assessment Sensitivities, Zurich Airport Case Study. 2012.

[5] International Civil Aviation Organization, ICAO Annex 16: Environmental Protection, Volume II - Aircraft Engine Emissions. 2008.

[6] Badami, M., Nuccio, P., Signoretto, A. Experimental and numerical analysis of a small-scale turbojet engine, Energy Conversion and Management. 2013, 76, 225-233.

[7] Benini, E., Giacometti, S. Design, manufacturing and operation of a small turbojet-engine for research purposes. Applied Energy. 2007, 84, 1102-1116.

[8] Badami, M., Nuccio, P., Pastrone, D., Signoretto, A. Performance of a small-scale turbojet engine fed with traditional and alternative fuels. Energy Conversion and Management. 2014, $82,219-228$.

Bartosz Gawron, DEng. - Research scientist at Air Force Institute of Technology, Warsaw. e-mail: bartosz.gawron@itwl.pl

\section{Conclusion}

In summary, the performance and emission characteristics of a miniature turbojet engine, using Jet A-1 fuel were studied. The presented results of exhaust gas emissions are not flawed due to combustion of the mixture of Jet A-1 with oil. This was achieved by the modification of the fuel supply system.

Tests were carried out according to determined profile of engine test, which characterises various operating modes of a miniature jet engine. The stability of engine operating parameters for a given rotational speed are reached very quickly. However, the exhaust gas emission - mainly COis characterized by instability. To achieve stability, optimal time periods of performing measurements on certain operating modes of the engine were determined. These times are different, depending on the rotational speed.

The presented profile of engine test seems to be authoritative in terms of real time measurements of exhaust gas emissions form a miniature jet engine. The adoption and application of unitary profile using MiniJETRig is particularly important during conducting comparative research of different fuels, including alternative fuels for aviation.

[9] Habib, Z., Parthasarathy, R., Gollahalli, S. Performance and emission characteristic of biofuel in a small-scale gas turbine engine. Applied Energy. 2010, 87, 1701-1709.

[10] Ibrahim, M.N., Ali, A.H.H., Ookawara, S. Experimental Study on Performance and Emissions of Turbojet Engine Fueled by Alternative Biodiesel. The 23 International Conference On: Environmental Protection is a Must.2013.

[11] Mendez, C.J., Parthasatathy, R.N., Gollahalli, S.R. Performance and emission characteristic of butanol/Jet A blends in a gas turbine engine. Applied Energy. 2014, 118, 135-140.

[12] Chmielewski. M., Gieras. M. Small Gas Turbine GTM-120 bench testing with emission measurements. Journal of KONES. $2015,22,47-54$

[13] Gawron, B., Białecki, T. The laboratory test rig with miniature jet engine to research aviation fuels combustion process. Journal of KONBIN. 2015, 36, 79-90.

[14] website of engine manufacturer - https://www.jetpol.tech/.

[15] Walsh, P.P., Fletcher, P. Gas Turbine Performance. Second Edition. 2004.

[16] Lefebvre, A.H., Ballal, D.R. Gas Turbine Combustion. Alternative Fuels and Emissions, Third Edition, 2010.

Tomasz Białecki, MSc Eng. - Head of Laboratory in the Division for Fuels and Lubricants at Air Force Institute of Technology, Warsaw. e-mail: tomasz.bialecki@itwl.pl

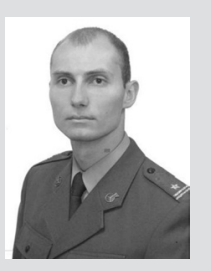

